\title{
Skuteczność wybranych herbicydów w uprawie sorga
}

\author{
Efficiency of some herbicides for weed control in sorghum
}

\section{Sylwiana Nowicka ${ }^{凶}$, Hubert Waligóra, Witold Skrzypczak}

\author{
Katedra Agronomii, Uniwersytet Przyrodniczy w Poznaniu ul. Dojazd 11, 60-632 Poznań \\ e-mail: sylwiana01@wp.pl
}

\begin{abstract}
Sorgo po pszenicy, kukurydzy, ryżu oraz jęczmieniu zajmuje piątą pozycję pod względem powierzchni upraw zbóż na świecie. Sorgo w początkowej fazie cechuje się powolnym wzrostem, co powoduje, że przez pewien czas międzyrzędzia pozostają niezakryte i w konsekwencji stwarza odpowiednie warunki do szybkiego wzrostu i rozwoju chwastów. Celem prowadzonych badań była ocena skuteczności i selektywności wybranych herbicydów stosowanych w uprawie sorgo na terenie Wielkopolski.
\end{abstract}

\begin{abstract}
Słowa kluczowe: sorgo, herbicyd, zachwaszczenie, skuteczność, selektywność
Sorghum after wheat, corn, rice and barley ranks fifth in terms of cereal area in the world. Sorghum in the initial phase is characterized by slow growth, which means that for some time the inter-glands remain uncovered and, as a consequence, creates appropriate conditions for rapid growth and development of weeds. The aim of the research was to evaluate the effectiveness and selectivity of selected herbicides used in sorghum cultivation in Wielkopolska.
\end{abstract}

Key words: sorghum, herbicide, weeds, efficiency, selectivity

Sorgo po pszenicy, kukurydzy, ryżu oraz jęczmieniu zajmuje piątą pozycję pod względem powierzchni upraw zbóż na świecie. Szczególnie dużą popularność osiągnęło w USA, Chinach, Nigerii, Sudanie, Australii oraz Meksyku (Popescu, Condei, 2014). W Europie i USA uprawiane jest przede wszystkim na cele paszowe, jednak części nadziemne mogą również być wykorzystane jako materiał budowlany, do produkcji paliw oraz biomasy (Sałagan i in., 2013). Natomiast w Afryce ziarno stanowi podstawowy produkt diety (Frankowski, 2017). Jest uważana za jedną $\mathrm{z}$ najstarszych roślin (Kaczmarek i in., 2012), której początki uprawy sięgają 4000 r. p.n.e. w Etiopii (Sołtys, 2010). Ze względu na swoje pochodzenie charakteryzuje się niewielkimi wymaganiami glebowymi oraz dużą odpornością na deficyt wody (Kaczmarek i in., 2009), co przyczynia się do wzrostu zainteresowania sorgiem $\mathrm{w}$ Polsce $\mathrm{w}$ ostatnich latach (Witkowski i in., 2017).

Sorgo w początkowej fazie cechuje się powolnym wzrostem, co powoduje, że przez pewien czas międzyrzędzia pozostają niezakryte i w konsekwencji stwarza odpowiednie warunki do szybkiego wzrostu i rozwoju chwastów (Skrzypczak, 2008). Chwasty pojawiające się wraz $\mathrm{z}$ rośliną uprawną lub krótko po jej wschodach mogą zmniejszyć produktywność sorga, a przy silnym zachwaszczeniu gatunkami chwastów jednoliściennych może powodować obniżenie plonu nawet o $20 \%$. Natomiast zachwaszczenie w późniejszym etapie wzrostu ma mniejszy wpływ na wielkość plonu, ale może utrudniać zbiór (Kaczmarek, 2009). Poprawnie wykonane zabiegi przed siewem wpływają na ograniczenie występowania chwastów, jednak nie gwarantują uzyskania satysfakcjonujących plonów, dlatego konieczne jest zastosowanie herbicydów. Sorgo w Polsce zaliczane jest do roślin małoobszarowych, dlatego brak jest zaleceń dotyczących regulacji zachwaszczenia. Powszechnie stosowane środki chemiczne chwastobójcze w tym gatunku rośliny uprawnej, mogą niekorzystnie wpływać na jej wzrost i rozwój (Kaczmarek, 2012).

Celem prowadzonych badań była ocena skuteczności i selektywności wybranych herbicydów stosowanych $\mathrm{w}$ uprawie sorgo na terenie Wielkopolski.

\section{Materiały i metody}

Doświadczenie zostało przeprowadzone na polach Zakładu Doświadczalno-Dydaktycznego w Swadzimiu, koło Poznania, w latach 2013-2014. Założone metodą bloków losowych, w 4 powtórzeniach. Zastosowane herbicydy przedstawiono w tabeli 1. Herbicyd Afalon Dyspresyjny 450 SC + Dual Gold 960 EC zastosowano bezpośrednio po siewie, a oprysk herbicydem Lumax 537,5 SE wykonano bezpośrednio po siewie oraz $\mathrm{w}$ fazie 3 liścia rośliny uprawnej. Zabiegi uprawowe i pielęgnacyjne były przeprowadzone zgodnie z przyjętymi zasadami dla uprawy sorgo. Stan zachwaszczenia oceniono 4 tygodnie po wykonanych zabiegach.

Podczas prowadzonych dwuletnich badań warunki pogodowe były sprzyjające wzrostowi sorgo. Srednie temperatury powietrza dla poszczególnych miesięcy były bardzo zbliżone i nie 
różniły się znacząco od średniej $\mathrm{z}$ wielolecia. Suma opadów w 2013 znacząco przewyższała średnią sumę z wielolecia, szczególnie w miesiącach: maj, czerwiec i wrzesień. Natomiast w 2014 roku suma opadów była zbliżona do średniej $\mathrm{z}$ wielolecia, jedynie $\mathrm{w}$ maju znacznie przewyższała średnią.

Tabela 1

Charakterystyka badanych herbicydów Characteristics of applied herbicides

\begin{tabular}{|c|c|c|c|}
\hline $\begin{array}{l}\text { Herbicyd } \\
\text { Herbicide }\end{array}$ & $\begin{array}{c}\text { Substancja } \\
\text { aktywna } \\
\text { Activ substance }\end{array}$ & $\begin{array}{c}\text { Dawka } \\
\text { Dose of } \\
\text { herbicide }\end{array}$ & $\begin{array}{c}\text { Termin zabiegu } \\
\text { Time of application }\end{array}$ \\
\hline $\begin{array}{c}\text { Afalon } \\
\text { Dyspresyjny } \\
\text { 450 SC + Dual } \\
\text { Gold } 960 \text { EC } \\
\end{array}$ & $\begin{array}{c}\text { linuron+ } \\
\text { s-metolachlor }\end{array}$ & $\begin{array}{l}2 \mathrm{l} / \mathrm{ha}+ \\
1,5 \mathrm{l} / \mathrm{ha}\end{array}$ & $\begin{array}{c}\text { Bezpośrednio po } \\
\text { siewie } \\
\text { Directly after sowing }\end{array}$ \\
\hline $\begin{array}{c}\text { Lumax } 537,5 \\
\text { SE }\end{array}$ & $\begin{array}{l}\text { terbutylazyna+ } \\
\text { mezotrion }+ \\
\text { s-metolachlor } \\
\end{array}$ & $3,5 \mathrm{l} / \mathrm{ha}$ & $\begin{array}{c}\text { Bezpośrednio po } \\
\text { siewie } \\
\text { Directly after sowing }\end{array}$ \\
\hline $\begin{array}{c}\text { Lumax } 537,5 \\
\text { SE }\end{array}$ & $\begin{array}{l}\text { terbutylazyna+ } \\
\text { mezotrion }+ \\
\text { s-metolachlor }\end{array}$ & $3,5 \mathrm{l} / \mathrm{ha}$ & $\begin{array}{l}\text { 3. liść } \\
\text { 3. leaf }\end{array}$ \\
\hline
\end{tabular}

\section{Wyniki i wnioski}

1. Dominującymi gatunkami chwastów w uprawie sorga były: komosa biała, chwastnica jednostronna, fiołek polny, rdest powojowy, tasznik pospolity.

2. Najwyższą skuteczność chwastobójczą zaobserwowano na obiektach po użyciu posiewnych herbicydów Afalon Dyspresyjny $450 \mathrm{SC}$ + Dual Gold 960 EC oraz Lumax 537,5 SE. W obu latach wykazały $100 \%$ skuteczność. Natomiast Lumax 537,5 SE stosowany w późniejszym okresie wzrostu rośliny uprawnej, w fazie 3 liści, w mniejszej ilości ograniczał zachwaszczenie.
3. W efekcie zastosowania każdego $\mathrm{z}$ herbicydów zaobserwowano wyraźny wzrost plonu świeżej masy sorga $\mathrm{w}$ porównaniu do obiektu kontrolnego. Najwyższy plon w obu latach uzyskano po zastosowaniu herbicydu Lumax 537,5 SE bezpośrednio po siewie. Na tych obiektach wielkość plonu wyniosła 65,4 ton/ha w 2013, a w 2014 roku 72,8 t/ha.

\section{Literatura}

Frankowski J. 2017. Właściwości odżywcze i lecznicze sorgo. Post Fitoter 18 (3): $209-214$.

Kaczmarek S., Matysiak K., Krawczyk R. 2009. Badania nad chemicznym odchwaszczaniem sorga zwyczajnego (Sorghum vulgare Perz.). Acta Sci. Pol., Agricultura 8 (1) 2009: 27 - 35 .

Kaczmarek S., Matysiak K., Kierzek R. 2012. Ocena wrażliwości Sorghum vulgare L. na wybrane substancje aktywne herbicydów. Nauka Przyroda Technologie. Tom 6, Zesz. 2: 27.

Popescu A., Condei R. 2014. Some considerations on the prospects of sorghum crop. Scientific Papers Series Management. Vol. 14, issue 3: $295-304$.

Sałagan P., Dobek T., Kołosowski P. 2013. Potencjał uzysku biogazu z sorga cukrowego (Sorghum bicolor) odmiany ród J 1052. Inżynieria Rolnicza Z. 4 (147) t. 1: 291 299.

Skrzypczak W., Waligóra H., Szulc P. 2008. Możliwości mechanicznego ograniczania zachwaszczenia w uprawie kukurydzy i sorga w rolnictwie ekologicznym. Journal of Research and Applications in Agricultural Engineering. Vol. 53 (4): $67-70$.

Sołtys D., Gniazdowska A., Bogatek R. 2010. Sorgoleongłówny związek warunkujący potencjał allelopatyczny sorga (Sorghum spp.). Kosmos. Tom 59, numer 3-4 (288-289): 567 - 579 .

Witkowski T., Foszczyńska B., Chmielewska J., Sowiński J., 2017. Sorgo jako komponent piw specjalnych. Acta Sci. Pol. Biotechnologia 16 (1-4), 107 - 114.

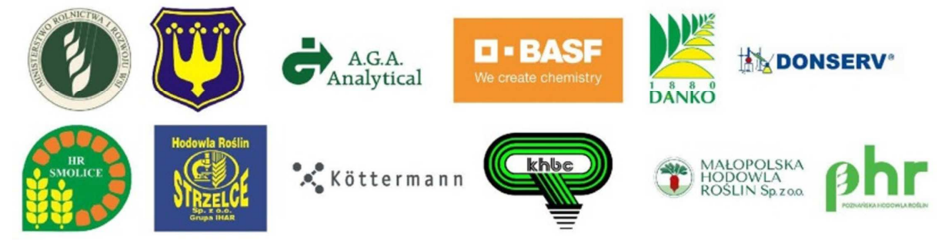

